This is an Accepted Manuscript of a chapter published by Taylor \& Francis Group in Graphic Justice: Intersections of Comics and Law, ed by Thomas Giddens, on 31/03/2015, available online:

https://www.routledge.com/Graphic-Justice-Intersections-ofComics-and-Law/Giddens/p/book/9781138787995 


\title{
Holy Blurring of Core Copyright Principles, Batmobile!
}

\author{
Kim Barker
}

\section{Introduction}

Comics are based around the adventures - and misadventures - of the characters that appear within them. ${ }^{1}$ Two successful comic series are those produced by DC ComicsBatman $^{2}$-and the Marvel series-The Avengers. ${ }^{3}$ These comics rely almost exclusively on their characters for their success. These characters are incredibly important-but also distinctive and valuable. As creative products, comics are protected by intellectual property; however, it is now possible that the characters appearing in these comics are also capable of protection in their own right. ${ }^{4}$ This chapter will consider the protection granted to comics, and to their characters, under the law of copyright, and will consider the challenges posed by such decisions, especially in light of the rapid expansion of fan fiction ${ }^{5}$ and fan fiction publishing outlets. This work discusses these issues in light of a recent decision protecting the Batmobile as a character in its own right, ${ }^{6}$ before evaluating the extent to which 'character' receives copyright protection.

\section{Characters and ComiX}

The recent decision in the US case of DC Comics $v$ Towle ${ }^{7}$ has determined that the 'Batmobile' is to be regarded as a character — one distinct from 'Batman' — and which benefits from individual copyright protection. This decision raises questions surrounding the extent to which characters are protected aside from other characters and other attributes in comics and other fictional works. It also represents a significant

\footnotetext{
${ }^{1}$ DC Comics v Towle, 2013 WL 541430 (CD Cal Feb 7 2013).

${ }^{2}$ See 'The Dark Knight-Batman' <http://www.dccomics.com/characters/batman> accessed 4February 2014.

${ }^{3}$ See 'Marvel Avengers: Alliance' <http://marvel.wikia.com/Marvel:_Avengers_Alliance> accessed 4 February 2014.

${ }^{4}$ DC Comics v Towle (n 1).

${ }^{5}$ Fan fiction is generally referred to as stories about characters or settings written by fans of the original works.

${ }^{6}$ DC Comics $v$ Towle (n 1). Indeed, this chapter argues that granting copyright protection to the Batmobile as a character is absurd - an absurdity that can be seen in the fact that using 'Batmobile' as one would any other character's name does not sit happily in a sentence: see the title of this chapter for an example.

${ }^{7}$ DC Comics v Towle (n 1).
} 
change in the legal landscape surrounding characters in literary works. ${ }^{8}$ There are now also a number of questions relating to the protection and intellectual property contained within works of fan fiction, which are heavily based upon characters from leading comics. The Batmobile decision is of further significance when it is placed in the context of this fan fiction, and moreover announcements by the ComiXology 9 platform in 2012: this platform now allows self-publishing of entire comics, ${ }^{10}$ allowing fans to write comics based on official comics or using the characters from leading comics. This could conceivably now include Batmobile comics; although, in light of the decision in DC Comics v Towle, there is potential for user-generated content, including fan fiction comics, to fall foul of copyright protection.

The ComiXology platform seems to encourage the sharing of works which may be based on characters from other comics. These could potentially be infringing the copyright in characters. ${ }^{11}$ Seemingly, the actions of ComiXology conflict with the decision in DC Comics $\mathrm{v}$ Towle and pose problems for user-generated content production.

\section{The Protective Rights-Based Regime}

In England and Wales, the Copyright, Designs and Patents Act 1988 (CDPA 1988) provides protection to a wide range of works ${ }^{12}$ from sound recordings ${ }^{13}$ and broadcasts ${ }^{14}$ to works such as films ${ }^{15}$ and newspapers. ${ }^{16}$ These works are all expressions of ideas. ${ }^{17}$ Another significant element relates to the fixation or capture in a permanent format of the work itself. The fixation requirement is particularly significant for literary, dramatic, musical or artistic works because there is a need for these works to be recorded or captured in some way in order to benefit from copyright protection. ${ }^{18}$ Without there being some form of capturing of the work, copyright

\footnotetext{
${ }^{8}$ Compare the decision of DC Comics $v$ Towle (n 1) to the predated decision in Warner Bros Pictures Inc v Columbia Broadcasting System, Inc 216 F 2d 945 (9th Cir 1954), where the court was categorical in stating that a character was not to be afforded distinct copyright protection.

${ }^{9}$ A cloud-based comics platform: see <http://www.comixology.com/about $>$.

10 'Self-Publishing Comic Books: ComiXology Launches "Submit" (Huffington Post, 3 July 2013) <http://www.huffingtonpost.com/2013/03/07/self-publishing-comic-bookscomixology_n_2829005.html> accessed 30 July 2013.

${ }^{11}$ DC Comics v Towle (n 1).

12 W Cornish, D Llewelyn and T Aplin, Intellectual Property: Patents, Copyright, Trademarks and Allied Rights (8th edn, Sweet and Maxwell 2013) 430-34.

13 s5B CDPA 1988.

${ }^{14}$ s6 CDPA 1988.

15 s5A CDPA 1988.

${ }^{16}$ As, for example, literary works under s3, but also as published arrangements under s8 CDPA 1988. See also: Newspaper Licensing Agencyv Marks \& Spencer [2001] Ch 257.

${ }^{17}$ Copyright is concerned with the protection of expressions rather than ideas. See below regarding the idea/expression dichotomy.

18 s3(2) CDPA 1988.
} 
subsistence cannot arise ${ }^{19}$ and the potential work will not benefit from copyright protection.

A literary work is defined within the CDPA 1988 as a work that is written. ${ }^{20}$ Protection is available for literary works, which encompasses protection for books-and works such as comics given their 'written' format, ie the use of images and text. ${ }^{21}$ It is possible that comics in particular benefit from additional artistic copyright due to the images and graphics that are merged with the text-based elements. Artistic works, for the purposes of copyright, include things such as graphic works. ${ }^{22}$ It is therefore possible that there will be more than one copyright subsisting in the comic as a work-literary copyright and artistic copyright. There is no legislative restriction as to the number of copyrights that can arise in a particular work. For example, it is usual for there to be more than one copyright in books-both the literary work, under s3 CDPA 1988, as well as the typographical arrangement, under s8 CDPA 1988. The question of multiple copyrights has arisen in copyright disputes, most notably in Critchley Components. ${ }^{23}$ Laddie $\mathrm{J}$ highlighted that there is no reason why one work cannot be protected by numerous copyrights. ${ }^{24}$ In relation to comics there is likely to be more than one creative effort involved, and on that basis it is unlikely that there will be difficulty in finding multiple copyrights in the same comics work. Two separate and distinct copyrights, potentially for different authors-literary copyright for the person(s) writing the words and artistic copyright for the graphical elements to the comic - are likely to subsist.

However, it is not always straightforward to identify what will be capable of being a 'work'. Deazley and Mathis consider the difficulty of identifying the 'work' forming the subject of copyright protection, ${ }^{25}$ indicating that there is already a 'problematic legal landscape'26 in the sphere of copyright, especially in terms of identifying what will form a work for the purposes of copyright. For example, the scope of copyright protection is difficult to identify if an artistic or literary work is not present. The challenge of identifying the category of works for comics to be protected under is compounded by their very nature. ${ }^{27}$ This is especially challenging when considering the differences between comics publishing compared to other forms of publishing. Many comics tend to be published in a series or a number of issues rather than a complete

\footnotetext{
${ }^{19}$ L Bently and B Sherman, Intellectual Property Law (3rd edn, OUP 2009) 58.

20 s3(1) CDPA 1988.

${ }^{21}$ P Torremans, Holyoak and Torremans Intellectual Property Law (7th edn, OUP 2013) 199. See also:

C Waelde et al, Contemporary Intellectual Property Law and Policy (3rd edn, OUP 2013) 56-82.

22 s4(1) CDPA 1988.

${ }^{23}$ Electronic Techniques (Anglia) Ltdv Critchley Components [1997] FSR 401.

${ }^{24}$ Ibid 412-13 (Laddie J).

${ }^{25} \mathrm{R}$ Deazley and J Mathis, 'Writing About Comics and Copyright' CREATe Working Paper No 9 (December 2013) <http://www.create.ac.uk/publications/writing-about-comics-and-copyright/> accessed January 2013.

${ }^{26}$ Ibid 9.

${ }^{27}$ S McCloud, Understanding Comics: The Invisible Art (HarperPerennial 1994) 1-23.
} 
story. As such, it is possible for debate to arise as to whether each of the comic issues benefits from copyright protection, or whether the collected story benefits from the protection, although there are decisions that indicate the courts protect works as a whole rather than in parts (albeit these are not comic specific cases).

Deazley and Mathis indicate that, depending upon the ways in which a comic is written, it may be possible to protect each page or each panel of a particular comic, ${ }^{28}$ perhaps even as individual works of art. The issue of protecting parts of a work or a whole work is one that has caused some difficulty in identifying the work benefitting from copyright protection. For example, in the case of Hyperion Records ${ }^{29}$ the court indicated that it was possible for individual notes in a classical composition to benefit from protection individually, although that was not the approach taken in the case. This was also an approach that was considered possible in the earlier case of Sweeney, ${ }^{30}$ where the court said that individual chapters of a book could be protected separately. This has, however, been a controversial issue that was seemingly resolved in Ladbroke v William Hill, ${ }^{31}$ where the House of Lords indicated that the correct approach to identifying the 'work' was to consider the work in its entirety. As such, it seems that whilst it is possible to protect individual elements of a work, one possible approach that has been adopted by the courts is to protect the work as a whole work, although this is an unresolved area of complexity, compounded if multiple authors are involved in creating a work.

The protection that is afforded to works such as comics ensures that their expressions are protected rather than the ideas embodied within them. This is a fundamental principle that underpins the law of copyright in England and Wales, and is better referred to as the idea/expression dichotomy. This principle originated in the late $1800 \mathrm{~s}^{32}$ and is still regarded as the defining principle of copyright in the absence of a statutory definition, and has been recently reiterated by the Court of Appeal in Designers Guild. ${ }^{33}$ Morritt LJ stated, 'copyright subsists not in ideas, but in the form in which the ideas are expressed'. ${ }^{34}$ This statement reiterated the principle identified at the turn of the 20th century. There are doubts-including the extent to which copyright protects ideas-surrounding whether or not the idea/expression dichotomy offers a useful approach in copyright scenarios, and it is submitted that there is no clear boundary between ideas and expressions. Learned Hand J suggests that the dichotomy can at best only offer generic guidance. ${ }^{35}$ This debate has been a lengthy one, with Peterson $\mathrm{J}$ in 1916 attempting to clarify this, indicating that if something is worth

\footnotetext{
28 Ibid 8.

${ }^{29}$ Hyperion Records Ltd v Sawkins [2005] EWCA Civ 565.

${ }^{30}$ Sweeney and another $v$ MacMillan Publishers Ltd and another [2001] All ER (D) 332 (Nov).

${ }^{31}$ Ladbroke Football Ltd $v$ William Hill Football Ltd [1964] 1 WLR 273.

${ }^{32}$ Hollinrake $v$ Truswell [1894] 3 Ch 420; the idea/expression dichotomy was first identified in the US case of Bakerv Selden 101 U S 99 (1879).

${ }^{33}$ Designers Guild Ltd v Russell Williams (Textiles) Ltd [2000] All ER (D) 1950.

${ }^{34}$ Ibid 128.

${ }^{35}$ Nichols v Universal Pictures, 45 F 2d 119 (2d Cir 1930).
} 
copying then it is worth protecting. ${ }^{36}$ If something like a comic (as a literary work), for example, falls within the definitions offered in the CDPA of 'works' 37 then it will benefit from copyright protection. It therefore seems that elements of comics fit within this uncertainty over idea and expression, in light of decisions such as that of $D C$ Comics v Towle, and the dichotomy has been weakened further.

Copyright protects literary works and within this category, protection is afforded to comics. What does not benefit from protection are the ideas embodied within the comics themselves. The fundamental basis for copyright rests on the expression of an idea, rather than an idea in itself, although as will be discussed below, this is now a point of debate.

\section{User-Generated Content, Fan Fiction and Copyright?}

User-generated content (UGC) is easily recognisable but difficult to define. The phrase refers to content which is produced by consumers and users, eg Amazon Customer Reviews, blogs, social media sites and uploaded photos. ${ }^{38}$ The Organisation for Economic Co-operation and Development (OECD) has identified UGC as being connected to the ability of internet users to express themselves online because the internet has developed to be something that now encourages participation-this is known as the "participative web'39 or Web 2.0. The OECD defines UGC as involving three elements: publication, creative effort, and creation outside of professional creative industries. ${ }^{40}$ Combining these factors with the idea that UGC is participative, the three elements suggest that there is some form of creative endeavour produced in a nontraditional industry or format published on the internet. Under this definition, creative endeavours such as fan fiction - and potentially comics - fall within the realm of UGC.

UGC can arise in a number of contexts. Perhaps some of the most notable examples have arisen with the rise in social media sites. Instagram is one-controversial ${ }^{41}$ example of a UGC platform: users share their images online, directly producing the

\footnotetext{
36 University of London Press v University Tutorial Press [1916] 2 Ch 601, 618 (Peterson J).

37 ss 1-8 CDPA 1988.

38 Financial Times, 'Definition of User Generated Content' (Financial Times Lexicon, 2014) <http://lexicon.ft.com/Term?term=user_generated-content-(UGC)> accessed 31 January 2014.

${ }^{39}$ OECD Working Party on the Information Economy, 'Participative Web: User Created Content Report' (OECD 2007) <http://www.oecd.org/internet/ieconomy/38393115.pdf> accessed 31 January 2014, 8.

40 Ibid 8.

${ }^{41}$ Instagram sparked controversy in late 2012 by changing its terms and conditions to claim ownership over all the images its users had posted through the Instagram service. See for details: M Warman, 'Facebook's Instagram Claims "Perpetual” Rights to Users' Photos' (The Telegraph, 18 December 2012) $<\mathrm{http}$ ://www.telegraph.co.uk/technology/social-media/9752288/Facebooks -Instagram-claimsperpetual-rights-to-users-photos.html> accessed 31 January 2014.
} 
content, which Instagram as a service relies upon and is consisted of. ${ }^{42}$ UGC also arises in specific comics contexts, and (as just seen) it is also possible to view online fan fiction as examples of UGC. Fan fiction, as defined by Schwabach, refers to 'Works derived from other works currently protected as intellectual property but not explicitly authorized and not commercially published' ${ }^{43}$

This differs from the approach adopted by the OECD in its consideration of the participative web, which provides the following definition:

Fan fiction is a term that describes creative writing (often short stories) that uses pre-existing characters from television, movies or other fiction. Fanfiction. net is such a fan site with thousands of stories, for instance, expanding on the tales of JK Rowling's characters in Harry Potter books. ${ }^{44}$

It is clear from the approaches adopted by Schwabach and by the OECD that fan fiction is the creation of works that are based on pre-existing works. Fan fiction is nothing new per se, and has existed since fictional worlds attracted their own distinct followings, ${ }^{45}$ but has become more visible since online publishing and self-publishing platforms rose to prominence. ${ }^{46}$ Schwabach credits the 'respectability' of fan fiction to the movement in the 1970s of fandom in light of the 1976 Star Trek: The New Voyages short stories collection, which combined fictional works written by fans with introductions written by the actors from the Star Trek TV show. ${ }^{47}$ This in some respects legitimised fan fiction movements where they had previously been deemed to be niche areas. The impact of the internet upon fan fiction generated a plethora of problems from a copyright perspective, including the publishing potential, ${ }^{48}$ not to mention potential infringements of established characters - for example Harry Potter ${ }^{49}$ — when used in derived works. The example of JK Rowling and the Harry Potter series forming a basis for fan fiction has arisen in the UK through the 'Barry Trotter' ${ }^{50}$ works. This is in

\footnotetext{
${ }^{42}$ See for example: R Ouzeau, 'Unlock the Power of User Generated Content on Instagram' (Statigram Blog, 14 January 2014) <http://blog.statigr.am/unlock-power-user-generated-content-instagram/> accessed 15 January 2014.

43 A Schwabach, Fan fiction and Copyright: Outsider Works and Intellectual Property Protection (Ashgate Publishing, 2011) 8.

${ }^{44}$ OECD, 'Participative Web' (n 39), 16.

${ }^{45}$ Schwabach (n 43) 9.

46 Ibid 14.

${ }^{47}$ Ibid 9.

${ }^{48}$ L Stendell, 'Fanfic and Fanfact: How Current Copyright Law Ignores the Reality of Copyright Owner and Consumer Interests in Fan Fiction' (2005) 58 Southern Methodist University Law Review 1551.

$49 \mathrm{~T} \mathrm{Wu}$, 'Harry Potter and the International Order of Copyright' (Slate, 27 June 2003) $<\mathrm{http}$ ://www.slate.com/articles/news_and_politics/jurisprudence/2003/06/harry_potter_and_the_interna tional_order_of_copyright.single.html> accessed 31 January 2014.

${ }^{50} \mathrm{P}$ England and D Meale, 'Barry Trotter and the Infringement of Copyright-Parody Rules in the UK' (2008) 178 Managing Intellectual Property, 34.
} 
addition to JK Rowling suing for alleged copyright infringement in the 'Tanya Grotter' works in Russia. Both the Tanya Grotter work and the Barry Trotter work are fan fiction works, and both derivative works have been published.

The suggestion that fan fiction is nothing other than UGC, and as such online publishing should not prove problematic, was the argument used as a defence in relation to the wildly popular Fifty Shades of Grey series ${ }^{51}$ when copyright infringement claims were lodged against a pornographic production of the work. ${ }^{52}$ The defence claimed that the original works could not benefit from copyright protection because they were already in the public domain and had been produced in high percentages on a variety of websites. An additional and more unusual claim arose that there could be no copyright in the Fifty Shades of Grey works because they were originally fan fiction based on the Twilight series. This is a compelling argument, and one which Sunshine and Cloak highlight needs attention in any creation of fan fiction: 'the fan fiction author needs to be mindful to avoid infringing the underlying work or risk losing copyright protection' ${ }^{53}$ Fischer highlights that a claim such as that made in this case places a substantial emphasis on the contractual licensing of any fan fiction site. ${ }^{54}$ This seems to emphasise the importance of reading End User License Agreements, ${ }^{55}$ especially when dealing with potentially valuable properties online. ${ }^{56}$

However, UGC differs from fan fiction in one significant way. UGC can be original, whereas fan fiction can be derivative; it is based on a previous work (and therefore is based on a work which will benefit from copyright protection). This poses problems for the copyright subsistence in fan fiction, largely because of the idea/expression dichotomy, and the basing of fan fiction on the original works. It also poses potential difficulties when determining whether there has been copyright infringement by someone producing fan fiction.

This is a particular problem when fan fiction is widely published and shared on fan fiction sites. A brief survey of one leading site $^{57}$ reveals that there are over 10,000 fan

\footnotetext{
${ }^{51}$ Fifty Shades Limited and Universal Studios LLC v Smash Pictures Inc No CV12-10111 (CD Cal 27 Nov 2012).

52 E Gardner, 'Universal Sues over "Fifty Shades of Grey” Porn Adaptation' (The Hollywood Reporter, 29 November 2012) <http://www.hollywoodreporter.com/thr-esq/fifty-shades-grey-porn-adaptation395478> accessed 2 February 2014.

${ }^{53}$ DB Sunshine and JT Cloak, 'Fifty Shades of Copyright' (Intellectual Property Magazine, May 2013), 47.

${ }^{54}$ MA Fischer, 'Fifty Shades of Grey and Fan Fiction: Do You Own Your User Generated Content?' (Lexology, 12 March 2013) <http://www.lexology.com/library/detail.asp x?g=5cd41c40-3d90-486d 8510-4a9f86dd7bfa> accessed 6 February 2014.

${ }^{55}$ Contractual agreements governing the relationship between the providers and users of software and websites, including fan fiction sites.

${ }^{56} \mathrm{~K}$ Barker, 'MMORPGing-The Legalities of Game Play' (2012) European Journal for Law and Technology 3(1), 1.

${ }^{57}$ Fan Fiction Net <https://www.fanfiction.net/comic/Batman/> accessed 30 August 2013.
} 
fiction stories relating to Batman alone. ${ }^{58}$ It is potentially a problem following the announcement by ComiXology that there is a move towards commercial selfpublication of fan fiction comics. The ComiXology platform is one that publishes online comics, and which in July 2013 announced that self-publishing of comics would be supported for the first time. This service allows fan fiction authors, and authors of their own comics, to submit them to the ComiXology platform and see them published. Whilst this was not the only platform to launch such a submission system-with Amazon also launching a similar service ${ }^{59}$ - it is one which focuses especially on comics and graphic works, and in light of problems surrounding not only copyright subsistence in comics, but also comic character copyright, it is a significant development. Given that comics are protected by copyright, and that UGC can include works of fan fiction, such developments provide broad challenges for copyright. These challenges are exacerbated in light of decisions indicating that comics characters are protectable by copyright in themselves.

\section{The Batmobile 'Character' Problem}

As discussed, copyright protection extends to the expressions of ideas rather than to the ideas themselves. In July 2013, Lew J, in a Californian court, decided that the Batmobile was a character and therefore capable of distinct copyright protection, paying scant regard to the question of design rights. In DC Comics v Towle, ${ }^{60} \mathrm{Mr}$ Towle had been operating 'Gotham Garages', 61 where customers could order replica vehicles based on the Batmobile from the 1989 Batman film, and the 1966 TV series. DC Comics, as the publisher of comic books featuring both the Batmobile and the Batman character, sued Towle for copyright infringement on the basis that Towle had been producing replica vehicles modelled on those that had appeared in the TV series, films and comics. The decision came before Lew $\mathrm{J}$, who, in considering his judgment, identified the significance of a character in any work of copyright.

If the idea/expression dichotomy is applied to the facts of DC Comics v Towle, it seems difficult to reach a conclusion other than the Batmobile replica cars being a different form of expression, and therefore protectable as a different work from the comic books, films and TV series. This would appear to be the correct stance, especially on the basis of what was determined in cases such as Designers Guild ${ }^{62}$ where a distinction was

\footnotetext{
58 'Self-Publishing Comic Books' (n 10).

${ }^{59}$ See for example: Kindle Direct Publishing <https://kdp.amazon.com/>.

${ }^{60}$ DC Comics v Towle (n 1).

${ }^{61}$ Gotham Garages <http://www.gothamgarage.net/cars.html>, although the website now indicates that Gotham Garages does not own the trademarks in vehicles such as 'Herbie the Lovebug' or the 'Munsters Koach.'

${ }^{62}$ Designers Guild (n 33). It may be observed that this is a UK authority, and the Batmobile decision is not; nevertheless, both the USA and the UK have adopted the idea/expression dichotomy as the fundamental basis for their respective copyright systems. In the USA, this was identified in the fundamental case of Bakerv Selden 101 U S 99 (1879).
} 
held between ideas and expressions. Surely, the expressions of the Batmobile in the comics and film were different from the expression in the form of a replica car by $\mathrm{Mr}$ Towle?

Nevertheless, the approach Lew $\mathrm{J}$ in DC Comics $v$ Towle followed was different. He stipulated that the Batmobile (in the comics, TV series and book) was a character which was particular and distinctive; therefore entitled to separate copyright protection. In making such a judgment, Lew $\mathrm{J}$ held that Mr Towle had been infringing the copyright of DC Comics. This was the decision reached, regardless of the fact that the Judge was aware that the Batmobile appeared differently each time it appeared:

The Batmobile is known by one consistent name that identifies it as Batman's personal vehicle. It also displays consistent physical traits ... Even though the Batmobile is not identical in every comic book, film or television show, it is still widely recognizable because it often contains bat-like motifs, such as bat-faced grill, or bat-shaped tailfins in the rear of the car, and it is almost always jet black. ${ }^{63}$

It is clear from the judgment that Lew $\mathbf{J}$ was aware of the differences between the various representations the Batmobile has taken on in different media. Nevertheless, he highlighted a variety of common features, which he indicated were distinctive enough to allow a finding of character in the Batmobile. The Judge also indicated that because the Batmobile had a distinctive character, and was protected by copyright, $\mathrm{Mr}$ Towle was infringing that copyright, even by transferring the expression of the Batmobile from a two-dimensional representation into a three-dimensional representation. ${ }^{64}$ This has proved to be a controversial decision, and is far from problem-free, because the scope of the judgment essentially means that even where there is a functional element to the expression a copyright finding of character will be sufficient for infringement to arise. ${ }^{65}$ The difficulty with this decision stems directly from the idea/expression dichotomy: the expression of the Batmobile in Mr Towle's car was a different expression from that in the comic books, film and TV series. If core copyright principles are applied, such a decision should not have arisen-it is within the scope of the law to provide protection for both expressions.

A similar issue arose in the Lucasfilm ${ }^{66}$ litigation in the $\mathrm{UK}$ in relation to whether or not copyright protection extended to replica Stormtrooper Helmets that had originally been made for the 1970s film, Star Wars Episode IV: A New Hope. The Supreme Court

\footnotetext{
${ }^{63}$ DC Comics v Towle (n 1) 37-38 (Lew J).

${ }^{64}$ DC Comics $v$ Towle (n 1) 39 (Lew J).

${ }^{65}$ KA Henry, 'Holy Copyrightability! The Batmobile is a Superhero...' (Media Law Monitor, 9 April 2013) <http://www.medialawmonitor.co m/2013/04/holy-copyrightability-batman-the-bat mobile-is -asuperhero/> accessed 30 August 2013.

${ }^{66}$ Lucasfilm Ltd v Ainsworth [2011] UKSC 39.
} 
was required to adjudicate on a copyright infringement claim arising in the helmets being produced by Ainsworth without permission of Lucasfilm. The Court considered that the helmets could potentially be capable of copyright protection, albeit not in this instance. This decision turned on the consideration given by the Court to the 'purpose' of the helmets, stipulating that there could be no copyright in the helmet because it was not the helmet forming the work of art:

It was the Star Wars film that was the work of art ... The helmet was utilitarian in the sense that is was an element in the process of production of the film. ${ }^{67}$

This reasoning, if applied to decisions like DC Comics $\mathrm{v}$ Towle, indicates that the decision made by Lew $\mathrm{J}$ could be correct, if the rationale was that the 'work of art' in question was something more than merely the Batmobile. As such, it is possible that the reasoning of Lew $\mathbf{J}$ was that protection had to be granted to the Batmobile as a character because it was an extension of Batman as a work of art. Whether this rationale would be applied in the UK is an interesting question. Irrespective of this, the decision reached in another UK case, Temple Islands $v$ New English Teas, ${ }^{68}$ also concerned the scope of copyright protection. This case was not concerned with character protection, but with the protection afforded to photographs that have been edited. The issue arose over a question of copyright infringement in images of the Houses of Parliament, taken with a London bus in the foreground, later edited so that there was a monochrome background with a red bus in the foreground. ${ }^{69}$ The two images, taken by different people, were similar but were taken from slightly different positions on the banks of the River Thames in London. Birss $\mathrm{J}$ in the Patents County Court was required to consider whether there had been copyright infringement, and held that there was infringement of the first image, although there are concerns as to whether or not this case establishes good law.

The implications of the Temple Islands decision are potentially significant, and evidence the emanation of the underlying confusion prevalent in the idea/expression dichotomy. ${ }^{70}$ The dichotomy does not protect ideas, ${ }^{71}$ yet the decision in Temple Islands has had the effect of giving protection to the underlying idea of editing the photograph rather than protecting two expressions of the same, or a very similar, idea.

\footnotetext{
67 Ibid at 44.

${ }^{68}$ Temple Island Collections Ltd v New English Teas Ltd \& Anor [2012] EWPCC 1.

69 See for example: 'The Wheels on the Birss' (The IPKat, 25 January 2012) <http://ipkitten.blogspot.co.uk/2012/01/wheels -on-birss.html> accessed 26 January 2014.

70 S Innes, 'Snaps: Temple Island Collections v New English Teas Ltd [2012] EWPCC 1' (Lexology, 3 April 2012) <http://www.lexology.com/library/detail.asp x?g=4a5a2656-512e-4036-96fb 2e7d63cd263c> accessed 14 January 2014.

${ }^{71} \mathrm{~S}$ Ang, 'The Idea-Expression Dichotomy and Merger Doctrine in the Copyright Law of the US and the UK' (1994) 2 International Journal of Law and Information Technology, 111; Hollinrake v Truswell [1894] 3 Ch 420; Designers Guild Ltd v Russell Williams (Textiles) Ltd [2000] All ER (D) 1950.
} 
Rahmatian indicates that the Court reached the correct decision, but that the law is to blame for producing the wrong result, ${ }^{72}$ but it is submitted that this is an unjustifiable legal position. Nevertheless, the Court did not consider in its judgment in Temple Islands the idea/expression dichotomy. Consequently, it seems that the effect of the Temple Islands, Lucasfilm and DC Comics v Towle cases have all weakened and blurred the dichotomy. In addition to that, it is also apparent that from the Temple Islands and DC Comics $v$ Towle judgments that copyright protection is extending to include protection of underlying ideas. This is likely to be particularly problematic given the ease with which fan fiction comics can be produced and published through platforms such as ComiXology.

DC Comics v Towle is not the only case concerning intellectual property rights in characters. Nor is it the only case discussing characters in cars. A related case dealing with rights in car characters is Halicki Films. ${ }^{73}$ This case was concerned with the copyright in the name of the car 'Eleanor' which had appeared in the original Gone in 60 Seconds. The dispute arose because of the Disney remake of the film in 2000, and the use of the rights to sell merchandise. The court was required to adjudicate on a number of issues relating to the character of the car, and, whilst not ruling that the car appearing in the original could be entitled to 'comic book-like copyright', ${ }^{74}$ did indicate that there were distinctive elements, which may allow such protection to arise. Brehm and May have suggested that the leading reason why such a finding could be possible is because of the particularly distinctive features the characters have. ${ }^{75}$ The Batmobile had its features discussed at length, with the Judge concluding that the features themselves were distinctive. ${ }^{76}$ Similarly, in Halicki 'Eleanor' was a bright yellow 1970s car-again, distinctive enough to be memorable.

There have been other US cases dealing with the protection afforded to characters under the law of copyright, although these have not-in contrast to the Batmobile and 'Eleanor' decisions - been concerned per se with physical embodiments of those characters. Schwabach indicates that the US courts have changed their scope of protection in relation to characters, using different tests. ${ }^{77}$ This change in approach from the US courts has meant that they adopted a strict stance in that characters were deemed to be un-protectable in the 1950s, yet that approach changed post-2012. The first test, indicating that characters are not protectable, arose in relation to the character of Sam Spade in The Maltese Falcon in 1954. ${ }^{78}$ The Court in this case indicated that

\footnotetext{
72 A Rahmatian, 'Temple Islands Collections v New English Teas: an incorrect decision based on the right law?' [2012] European Intellectual Property Review 796.

${ }^{73}$ Halicki Films LLC v Sanderson Sales and Marketing 547 F 3d 1213, (9th Cir. 2008).

${ }^{74}$ Ibid.

75 AS Brehm and EW May, 'Copyright Protection for Fictional Characters' (2012) 84 Bloomberg BNA's Patent, Trademark and Copyright Journal 285.

${ }^{76}$ DC Comics v Towle (n 1) 37-38 (Lew J).

77 Schwabach (n 43) 28.

${ }^{78}$ Warner Bros Pictures Inc v Columbia Broadcasting System Inc 216 F 2d 945 (9 th $^{\text {Cir } 1954) . ~}$
} 
irrespective of the assignability or otherwise of copyright in The Maltese Falcon, there was no copyright in the character Sam Spade: 'The character is only the chessman in the game of telling the story, he is not within the protection afforded by copyright' ${ }^{79}$

This restrictive approach seems consistent with the idea/expression approach to copyright. The Sam Spade character, under this restrictive approach or the so-called 'story-being told' 80 test, did not benefit from copyright protection. This is perhaps because of the claim made by the author Hammett in the 1934 edition: 'Spade has no original. He is a dream man. ${ }^{\text {'81 }}$ This is reiterated by Schwabach, who indicates that there were no particularly distinctive features of Sam Spade. ${ }^{82}$ It is perhaps this that distinguishes the 1954 decision, from the much later cases of DC Comics v Towle and Halicki.

The second test, known as the 'sufficiently delineated' test, was adopted initially in Air Pirates, ${ }^{83}$ where the Court indicated the shortcomings of the 'story being told test' when applied to characters accompanied by graphical representations. It is therefore apparent that under the 'story being told' test it is unlikely that the Batmobile of Mr Towle would have been found to be infringing copyright on the basis that there is no copyright in characters. However, under the less restrictive 'sufficiently delineated' test, which focuses on the character being drawn so sufficiently that the representation of the character moves from an idea to being an expression, it is:

plausible to interpret Air Pirates as applying a less stringent test for protectability of graphic characters ... As a practical matter, a graphically depicted character is much more likely than a literary character to be fleshed out in sufficient detail so as to warrant copyright protection. ${ }^{84}$

Under this interpretation, adopted in $1989,{ }^{85}$ it is clear that the Courts have adopted a lower threshold which identifies that there will be more detail required in order to protect a character under copyright. Nevertheless, this is not without its problems. And it is within such vagueness as 'sufficient detail' that decisions like DC Comics v Towle are made. This again blurs the lines between idea and expression, and is likely to prove problematic in subsequent cases.

\section{The Blurring of Ideas-A Comic Tragedy?}

\footnotetext{
${ }^{79}$ Halicki Films LLC (n73) 1224.

${ }^{80}$ Schwabach (n 43) 24.

${ }^{81}$ D Hammett, The Maltese Falcon (introduction) 1934.

<http://www.thrillingdetective.com/trivia/triv 244.html> accessed 31 January 2014.

${ }^{82}$ Schwabach, Fan Fiction and Copyright (n 43) 29.

${ }^{83}$ Walt Disney Productions v Air Pirates 581 F 2d 751 (9 $9^{\text {th }}$ Cir 1978).

${ }^{84}$ Anderson v Stallone No 87-0592, 1989 WL 206431 (CD Cal 1989).

${ }^{85}$ Ibid.
} 
The decision relating to the Batmobile is concerning for fans of the Batman series, be it films, comic books or a television series. Fan fiction has to begin somewhere, and that is very often with the original work, and the original expression of a character. If, as indicated in the US cases, characters are protected by copyright, it is highly likely that fans who continue to produce fan fiction based on the leading characters - such as Batman and the Batmobile-will fall foul of copyright laws. This is even more likely given the volume of fan fiction, which is published through online platforms such as ComiXology.

Digital platforms like ComiXology encourage creativity, and reflect the underpinnings of the intellectual property system. However, whilst encouraging creativity, they are also simultaneously encouraging users and fans to engage in activities which may lead to copyright infringement. This is particularly problematic in light of the DC Comics $v$ Towle decision that subordinate characters in established comics can benefit from protection. The Court, in making such a determination, may have reached the correct decision based on the facts. The Court in DC Comics v Towle equally may have made the incorrect decision, especially after the decision in Lucasfilm, where the focus rested on the utilitarian function and purpose of the items created. In focussing on the purpose here, the Batmobile was part of the film and was not part of the original expression, so does not fall within the copyright of the Batmobile. By protecting a character the court has stretched the boundaries of copyright, and has twisted-perhaps irreparably - the distinction between ideas and expressions. It seems from the decision that underlying ideas - such as the Batmobile - are now protected by copyright, rather than the expression of them.

If the Court had protected the expression of the Mr Towle's Batmobile, rather than the Batmobile per se, the scope of copyright would not have been damaged. The Court could have made such a decision on the basis of UGC justifications-Mr Towle's Batmobile is his expression of the idea behind the Batmobile. The decision in the USA seems to do something very similar to that which was done in the UK case of Temple Islands - the law has been interpreted and applied by both courts in two different jurisdictions, and in their application they have given protection to the ideas underlying expressions rather than the expressions themselves. In addition to this, they have significantly altered the potential for fiction, and that detracts not only from the characters themselves, but also from the enjoyment of those characters. UGC and fan fiction enterprises have had their creative freedom curtailed by two problematic decisions which have changed the scope of copyright protection.

\section{List of Cases}

Anderson v Stallone No 87-0592, 1989 WL 206431 (CD Cal 1989)

Baker v Selden 101 U S 99 (1879)

DC Comics v Towle, No CV11-03934 RSWL (OPx) (CD Cal Feb 7, 2013)

Designers Guild Ltd v Russell Williams (Textiles) Ltd. [2000] All ER (D) 1950 
Electronic Techniques (Anglia) Ltdv Critchley Components [1997] FSR 401

Fifty Shades Limited and Universal Studios LLC v Smash Pictures Inc No CV12-10111

(CD Cal 27 Nov 2012)

Halicki Films LLC v Sanderson Sales and Marketing 547 F 3d 1213, (9th Cir 2008)

Hollinrake v Truswell [1894] 3 Ch 420

Hyperion Records Ltdv Sawkins [2005] EWCA Civ 565

Ladbroke Football Ltd v William Hill Football Ltd [1964] 1 WLR 273

Lucasfilm Ltd v Ainsworth [2011] UKSC 39

Newspaper Licensing Agency v Marks \& Spencer [2001] Ch 257

Nichols $v$ Universal Pictures, 45 F 2d 119 (2d Cir 1930)

Sweeney and another $v$ MacMillan Publishers Ltd and another [2001] All ER (D) 332 (Nov)

Temple Island Collections Ltd v New English Teas Ltd \& Anor [2012] EWPCC 1

University of London Press v University Tutorial Press [1916] 2 Ch 601

Walt Disney Productions v Air Pirates, 581 F.2d 751 ( $9^{\text {th }}$ Cir 1978)

Warner Bros Pictures Inc. v Columbia Broadcasting System Inc 216 F 2d 945 ( $9^{\text {th }}$ Cir 1954)

\section{Bibliography}

Ang S, 'The Idea-Expression Dichotomy and Merger Doctrine in the Copyright Law of the US and the UK.' 2 International Journal of Law \& Information Technology (1994) 111

Barker K, 'MMORPGing - The Legalities of Game Play'. European Journal for Law and Technology, 3(1), 1 (2012)

Bently L and Sherman B, Intellectual Property Law ( $3^{\text {rd }}$ edn, OUP 2009)

Brehm AS and May EW, 'Copyright Protection for Fictional Characters' Bloomberg BNA's Patent, Trademark \& Copyright Journal, 84 PTCJ 285, 5

Cornish W, Llewellyn D and Aplin T, Intellectual Property: Patents, Copyright, Trade marks and Allied Rights ( $8^{\text {th }}$ edn, Sweet \& Maxwell, 2013)

Deazley R and Mathis J, 'Writing About Comics and Copyright' CREATe Working Paper No. 9 (December 2013) <http://www.create.ac.uk/publications/writingabout-comics-and-copyright/> accessed January 2013

England P and Meale D, 'Barry Trotter and the Infringement of Copyright-Parody rules in the UK' No 178 Managing Intellectual Property (34) [2008]

Fan Fiction Net. <https://www.fanfiction. net/comic/Batman/> accessed 30 August 2013

Financial Times, 'Definition of User Generated Content' Financial Times Lexicon (2014). <http://lexicon.ft.com/Term?term=user_generated-content-(UGC)> accessed 31 January 2014

Fischer MA, 'Fifty Shades of Grey and fan fiction: do you own your user generated content?'

(Lexology,

$12 \quad$ March

2013)

$<$ http:/www.lexology.com/library/detail.asp x?g=5cd41c40-3d90-486d-85104a9f86dd7bfa> accessed 6 February 2014 
Gotham Garages <http://www.gothamgarage.net/cars.html> accessed 6 February 2014 Gardner E, 'Universal Sues over 'Fifty Shades of Grey' Porn Adaptation' (The Hollywood Reporter, 29 November 2012) $<$ http://www.hollywoodreporter.com/thr-esq/fifty-shades-grey-porn-adaptation395478> accessed 2 February 2014

Hammett D, The Maltese Falcon (introduction) 1934: <http://www.thrillingdetective.com/trivia/triv244.html> accessed 31 January 2014 Henry KA, 'Holy Copyrightability! The Batmobile is a Superhero...' (Media Law Monitor 9 April 2013) <http://www.medialawmonitor.com/2013/04/holycopyrightability-batman-the-batmobile-is-a-superhero/> accessed 30 August 2013

Innes S, 'Snaps: Temple Island Collections v New English Teas Ltd [2012] EWPCC

1.' (Lexology, 3 April

2012)<http://www.lexology.com/library/detail.aspx?g=4a5a2656-512e-4036-

96fb-2e7d63cd263c> accessed 14 January 2014

Kindle Direct Publishing <https://kdp.amazon.com/>

Marvel Avengers: Alliance (<http $/ /$ marvel.wikia.com/Marvel:_Avengers_Alliance $>$ ) accessed 4 February 2014

McCloud S, Understanding Comics: The Invisible Art (HarperPerennial 1994) 1-23.

OECD Working Party on the Information Economy: Participative Web: User Created Content Report (2007) DSTI/ICCP/IE(2006)7/FINAL

$<$ http:/www.oecd.org/internet/ieconomy/38393115.pdf> accessed 31 January 2014

Ouzeau R, 'Unlock the Power of User Generated Content on Instagram' (Statigram Blog, 14 January 2014) <http//blog.statigr.am/unlock-power-user-generatedcontent-instagram/> accessed 15 January 2014

Rahmatian A, 'Temple Islands Collections v New English Teas: an incorrect decision based on the right law?' [2012] European Intellectual Property Review 796

Schwabach A, Fan fiction and Copyright: Outsider Works and Intellectual Property Protection' (Ashgate Publishing, 2011)

'Self-Publishing Comic Books: ComiXology Launches "Submit" (Huffington Post UK, 3 July 2013) <http://www.huffingtonpost.com/2013/03/07/self-publishingcomic-books-comixology_n_2829005.html?utm_hp_ref $=$ tw $>$ accessed 30 July 2013

Stendell L, 'Fanfic and Fanfact: How Current Copyright Law Ignores the Reality of Copyright Owner and Consumer Interests in Fan fiction' 58 Southern Methodist University Law Review 1551 (2005)

Sunshine DB and Cloak JT, 'Fifty Shades of Copyright,' (Intellectual Property Magazine, May 2013), 47

The Dark Knight-Batman <http $/ /$ www.dccomics.com/characters/batman> accessed 4 February 2014

The IPKat, 'The Wheels on the Birss' (25 January 2012): <http://ipkitten.blogspot.co.uk/2012/01/wheels-on-birss.html> accessed 26 January 2014

Torremans P, Holyoak \& Torremans Intellectual Property Law ( $7^{\text {th }}$ edn, OUP 2013) 
Waelde et al, Contemporary Intellectual Property Law and Policy ( $3^{\text {rd }}$ edn, OUP 2013)

Warman M, 'Facebook's Instagram claims 'perpetual' rights to users' photos' (The Telegraph, London, 18 December 2012): $<$ http://www.telegraph.co.uk/technology/social- media/9752288/FacebooksInstagram-claims-perpetual-rights-to-users-photos.html> accessed 31 January 2014

Wu T, 'Harry Potter and the International Order of Copyright' (Slate, 27 June 2003): <http://www.slate.com/articles/news_and_politics/jurisprudence/2003/06/harry_p otter_and_the_international_order_of_copyright.single.html > accessed 31 January 2014 